DOI: 10.33766/2524-0323.91.139-150 УДК 349.2

М. Ю. Покальчук, кандидат юридичних наук, асистент кафедри земельного та аграрного права Національного юридичного університету імені Ярослава Мудрого

(м. Харків, Україна)

e-mail: pokalchukm@gmail.com iD https:/ / orcid.org/0000-0003-3463-4098

Р. В. Дорошенко, студент 4 курсу Інституту прокуратури та кримінальної юстиції Національного юридичного університету імені Ярослава Мудрого

(м. Харків, Україна) e-mail: rdvicktorovich@gmail.com iD https:/ / orcid.org/0000-0002-6652-1664

К. С. Шанталій, студентка 4 курсу Інституту прокуратури та кримінальної юстиції Національного юридичного університету імені Ярослава Мудрого (м. Харків, Україна) e-mail: shantaliy99@gmail.com iDhttps://orcid.org/0000-0001-5444-2494

\title{
ПЕРСПЕКТИВИ РОЗВИТКУ СІМЕЙНИХ ФЕРМЕРСЬКИХ ГОСПОДАРСТВ ТА ПРОГАЛИНИ В ПРАВОВОМУ РЕГУЛЮВАННІ ЇХ ДІЯЛЬНОСТІ
}

Стаття присвячена дослідженню сучасного стану правової регламентації інституту фермерства. Авторами проаналізовано низку нормативно-правових актів часів УРСР, які регулювали порядок створення та діяльності селянських (фермерських) господарств. Висвітлено еволюцію фермерського господарства, починаючи з часів УРСР і до сьогодення. У статті досліджено поняття фермерського господарства крізь призму вітчизняного та зарубіжного законодавства. Проаналізовано Закон України від 19.06.2003p. № 973-15 «Про фермерське господарство», Господарський кодекс України, Податковий кодекс України та інші законодавчі акти, які встановлюють правове регулювання сімейних фермерських господарств в Україні. Авторами проаналізовано норми Закону, які регулюють порядок створення та діяльності сімейних фермерських господарств. Також досліджено стан законодавства щодо прогалин у правовому регулюванні сімейних фермерських господарств.

Ключові слова: аграрне право; фермерське господарство; сімейне фермерсьське господарство; аграрні правовідносини; сільське господарство; сімейне фермерське господарство без статусу юридичної особи; агропромисловий комплекс.

(C) Покальчук М. Ю., Дорошенко Р. В., Шанталій К. С., 2020 
Постановка проблеми. На тлі постійного реформування аграрного сектору економіки, а також на шпяху становлення України як аграрної держави, законодавче врегулювання питання створення, діяльності та функціонування сімейних фермерських господарств $є$ надзвичайно актуальним. Для того щоб аграрний сектор економіки гармонійно розвивався на ряду з іншими секторами економіки, існує потреба усунення прогалин у законодавстві шляхом їх подалышого доопрацювання. Оскільки в Україні існує ряд нерозв'язаних проблем, які стримують подалыший розвиток дрібного товаровиробництва, то дослідження питання створення, діяльності та функціонування сімейних фермерських господарств потребує поглибленого вивчення, а також упровадження в законодавство отриманих результатів.

Аналіз останніх досліджень і публікацій. Проблемі становлення, функціонування та ефективного розвитку сімейних фермерських господарств, як однієї з форм підприємницької діяльності під час ринкових перетворень в економіці країни, зокрема в аграрному секторі, присвячені роботи багатьох науковців, а саме: Н. В. Добрової, М. С. Долинської, Н. М. Оніщенко, М. М. Осипової, О. О. Погрібного, Т. П. Проценко, Н. І. Титової, В. В. Устюкової, Г. В. Чубукова, В. Ю. Уркевича тощо. Незважаючи на значну кількість науковців, що досліджували це питання, і досі залишаються невирішеними окремі суперечності та не усунуті прогалини в сімейному фермерському законодавстві.

Формулювання цілей. Метою статті є висвітлення нормативно-правових актів, які регулювали діяльність сімейних фермерських господарств під час ринкових перетворень в економіці країни; дослідження поняття та правових основ діяльності фермерського господарства, зокрема сімейного фермерського господарства, через призму українського законодавства; проведення аналізу наявних прогалин у законодавстві, яке встановлює режим правового регулювання сімейних фермерських господарств як однієї з організаційно-правових форм господарювання в Україні.

Виклад основного матеріалу. За даними Державної служби статистики України, станом на 1 квітня 2020 р. налічувалося 47,22 тис. фермерських господарств, без урахування тимчасово окупованої території Автономної Республіки Крим і міста Севастополя [1].

Із цього випливає, що на сьогодні фермерське господарство можна віднести до однієї з найефективніших форм ведення сільського господарства. Воно посідає вагоме місце серед інших суб'єктів аграрного виробництва.

Як зазначав відомий американський інвестор та аналітик Джим Роджерс: «У найближчі 30 років фермери стануть найбагатшими людьми на планеті. Якби я вирішив інвестувати в сільське господарство, я б став фермером або ж вклав гроші у фермера. Якщо уряд України захоче допомогти своїм аграріям - вони незабаром будуть їздити на люксових авто». Саме тим, що Україна має потенщіал у розвитку аграрного сектору економіки, і зумовлений підвищений інтерес із боку науковців щодо висвітлення теми дослідження фермерських господарств [2].

Традищія законодавчого регулювання діяльності фермерських господарств в Україні бере свої корені з часів УРСР.

Одними з перших кроків на шляху правового врегулювання взаємовідносин, які стосувалися б створення, діяльності та припинення існування селянських (фермерських) господарств, є прийняття Закону УРСР «Про пріоритетність соціального розвитку села та агропромислового комплексу в народному господарстві України» від 
17 жовтня 1990 р., Закону УРСР «Про пріоритетність соціального розвитку села та агропромислового комплексу в народному господарстві України», Постанови Верховної Ради України «Про земельну реформу» від 18 грудня 1990 р. та Постанови Кабінету Міністрів України від 20 липня 1991 р. № 96 «Про розвиток селянських (фермерських) господарств».

Закон УРСР «Про пріоритетність соціального розвитку села та агропромислового комплексу в народному господарстві України» окреслив умови, положення, сутність переваг щодо соціального розвитку села та агропромислового комплексу в системі народного господарства. Закон установлював рівність усіх форм власності в аграрному секторі та розкрив організаційно-правові й соціально-економічні принципи щодо забезпечення пріоритетності соціального розвитку села та агропромислового комплексу.

Більшість фермерських господарств, а саме близько 35 тис, були засновані в період із 1991 по 1995 рр. Одним із перших законів незалежної України, який започаткував створення та розвиток фермерських господарств, був Закон України від 20.12.1991 р. «Про селянське (фермерське) господарство» [3]. Цей Закон протягом десятиліть зазнавав певних змін та доповнень, що зумовлені реформуванням аграрного сектору економіки. Наприклад, із Закону зникло одне із суперечливих положень щодо першочерговості права на створення селянського (фермерського) господарства громадян, що проживають у сільскій місцевості. А в 1999 р. ч.1 ст. 25 (на момент редакщії Закону від 1999 р.) Закону було доповнено положенням щодо можливості селянського фермерського господарства самостійно визначати розмір готівки, що постійно знаходиться в його касі, на поточні витрати.

Проте, не всі ці зміни можна назвати такими, що докорінно змінюють правила гри. Застосування такого Закону на практищі виявило низку прогалин у ньому, і вже 19 червня 2003 р. було прийнято новий Закон, який, для прикладу, уточнював граничні розміри земельних ділянок, що можуть передаватись у приватну власність або в користування для ведення фермерського господарства [4, с. 141].

Слід зазначити, що на сьогодні зазначені нормативно-правові акти втратили чинність, та їх місце посідають: Конституція України, Земельний кодекс України, Господарський кодекс України та Закон України від 19.06.2003p. №973-15 «Про фермерське господарство».

У Законі України від 19.06.2003р. № 973-15 «Про фермерське господарство», який $\epsilon$ спеціальним нормативно-правовим актом у системі актів фермерського законодавства, визначено правові, економічні та сощіальні засади створення та діяльності фермерських господарств як прогресивної форми підприємницької діяльності громадян у галузі сільского господарства України. Саме у вищезазначеному Законі виявляється повне та всебічне правове забезпечення діяльності фермерських господарств, як результат багаторічної роботи законодавця в цому напрямку з урахуванням багатоаспектного досвіду діяльності селянських (фермерських) господарств у минулому.

В Україні фермерське законодавство представлено, окрім Закону України від 19.06.2003p. №973-15 «Про фермерське господарство», також низкою постанов Кабінету Міністрів України, наприклад: «Про порядок викупу земельних ділянок громадянами (понад норму, яка приватизується безкоштовно) для ведення фермерського або особистого підсобного господарства» від 24 січня 2000 р. № 118; «Про затвердження Порядку використання коштів державного бюджету для надання підтримки фермерським господарствам» від 25 серпня 2004 р. № 1102 тощо [5, с. 211]. 
Відповідно до ст. 1 Закону України від 19.06.2003р. № 973-15 «Про фермерське господарство», фермерське господарство - це форма піпприємнищької діяльності громадян, які виявили бажання виробляти товарну сільськогосподарську продукцію, здійснювати їі переробку та реалізацію з метою отримання прибутку на земельних ділянках, наданих їм у власність та/або користування, у тому числі в оренду, для ведення фермерського господарства, товарного сільськогосподарського виробництва, особистого селянського господарства, відповідно до Закону [6].

Галузеве законодавство при визначенні поняття фермерського господарства трактує його відповідно до власних цілей та предмету регулювання. Наприклад, у ст. 114 Господарського кодексу України фермерське господарство визначено як форму підприємництва громадян із метою виробництва, переробки та реалізації товарної сільськогосподарської продукції [7]. А згідно з п.209.6 ст. 209 Податкового кодексу України, сільськогосподарським вважається підприємство, основною діяльністю якого є постачання вироблених (наданих) ним сільськогосподарських товарів (послуг) на власних або орендованих основних фондах, а також на давальницьких умовах, у якій питома вага вартості сільськогосподарських товарів/послуг становить не менш як 75 відсотків вартості всіх товарів/послуг, поставлених протягом попередніх 12 послідовних звітних податкових періодів сукупно [8].

Визначення фермерського господарства, окрім національного законодавства, міститься також і в міжнародних нормативно-правових актах. Наприклад, відповідно до ст. 4 Регламенту Свропейського Союзу Свропейського Парламенту і Ради від 17.12.2013 № 1307/2013 щодо встановлення правил для прямих виплат фермерам згідно зі схемами підтримки як складника спільної аграрної політики та скасування Регламенту Ради № 637/2008 і Регламенту Ради № 73/2009, фермером є фізична чи юридична особа або група фізичних чи юридичних осіб, незалежно від правового становища, наданого такій групі і їі членам за національним правом, які здійснюють сільськогосподарську діяльність [9].

Підсумовуючи зазначене, зауважимо, що спільним для норм як національного, так і зарубіжного законодавства, які регулюють створення та діяльність сімейних фермерських господарств, є можливість існування сімейного фермерського господарства без набуття статусу юридичної особи.

Як і в попередніх редакціях Закону України від 19.06.2003р. «Про фермерське господарство», згідно з ч. 2 ст. 1 Закону, засновниками сімейного фермерського господарства повинні бути лише громадяни України. Окрім того, фермерське господарство може бути створене однією особою.

Таким чином, відповідно до п. п. 4,5 ст. 63 Господарського кодексу України, фермерське господарство може розглядатись і як унітарне пілптиємство, і як корпоративне. Загальновідомо, що унітарним визнається підприємство, що створюється одним засновником, який виділяє необхідне для того майно, формує відповідно до закону статутний фонд, не поділений на частки (паї), затверджує статут, розподіляє доходи, безпосередньо або через керівника, котрий ним призначається, керує підприємством і формує його трудовий колектив на засадах трудового найму, вирішує питання реорганізації та ліквідації підприємства. Своєю чергою, корпоративне підприємство утворюється, як правило, двома або білыше засновниками за їхнім спільним рішенням (договором), діє на основі об'єднання майна та/або підприємницької чи трудової діяльності засновників (учасників), їхнього спільного управління справами, 
на основі корпоративних прав, у тому числі через органи, що ними створюються, участі засновників (учасників) у розподілі доходів та ризиків підприємства [7].

Зауважимо, що тривалий час на практищі виникали суперечки щодо необхідності під час створення сімейного фермерського господарства його подалышої реєстращії як юридичної особи. Фактично, донедавна вимоги Закону щодо реєстращії фермерського господарства як юридичної особи не існувало. Змінами до ЗУ «Про фермерське господарство, внесеними, відповідно до ЗУ «Про внесення змін до ЗУ «Про фермерське господарство» від 31 березня 2016 р., було поставлено крапку в дискусії щодо необхідності реєстращії фермерських господарств як юридичних осіб. Відтак, відповідно до ч.4 ст. 1 ЗУ «Про фермерське господарство», фермерське господарство підлягає державній реєстрації як юридична особа або фізична особа-підприємець. Притому, як і будь-яка юридична особа, фермерське господарство діє на основі установчого документа, для юридичної особи - на підставі статуту, для господарства без статусу юридичної особи - на основі договору про створення фермерського господарства.

До того ж, ці зміни стали поштовхом до правового закріплення нового суб'єкта в аграрно-правових відносинах - фермерського господарства без створення юридичної особи - фізичної особи-підприємця, якого раніше не було.

Відповідно до абз.2 ч.2 ст. 81 Закону України «Про фермерське господарство», у разі створення фермерського господарства виключно однією особою без статусу юридичної особи, останньому не потрібно укладати договір про створення фермерського господарства; ця особа подає Декларацію про створення сімейного фермерського господарства. У ч.6 ст. $8^{1}$ цього ж Закону вказано, що Типова форма договору (декларащії) про створення сімейного фермерського господарства затверджується центральним органом виконавчої влади, що забезпечує формування державної аграрної політики. Наказом від 05.04.2019 р. № 177 Міністерства аграрної політики та продовольства України «Про затвердження типової форми договору (декларації) про створення сімейного фермерського господарства» затверджено типову форму Договору (декларації) про створення сімейного фермерського господарства [10].

Зауважимо, що вищевказаним Наказом передбачена форма установчого документа, який укладається під час створення сімейного фермерського господарства одноосібно або декількома особами. На нашу думку, типова форма установчого документа для одноосібного створення сімейного фермерського господарства без статусу юридичної особи повинна бути окремо передбачена. Це пояснюється неоднорідністю характеру правовідносин під час створення сімейного фермерського господарства.

Договір - це домовленість двох і білышесторін, спрямована на встановлення, зміну або припинення цивільних, і не тільки, прав та обов' язків [11]. Із визначення вбачається обов'язкова наявність двох сторін. Отже, у разі одноосібного створення сімейного фермерського господарства друга сторона відсутня, а передбачена законодаством типова форма договору (декларащіiі) про створення сімейного фермерського господарства підлягає застосуванню виключно в разі його створення кількома особами. Відповідно, існує необхілність передбачення типової форми установчого документа для одноосібного створення сімейного фермерського господарства.

У ст. 1 Закону України «Про фермерські господарства», а саме в ч.5, закріплені ознаки сімейного фермерського господарства. Відтак, відповідно до ч.5 ст. 1 вказаного 
Закону, фермерське господарство, зареєстроване як юридична особа, має статус сімейного фермерського господарства за умови, що в його пілприємницькій діяльності використовується праця членів такого господарства, якими є виключно члени однієї сім'ї відповідно до положень Сімейного кодексу України.

За словами В. Ю. Уркевича, негативнимє те, що в наведеному новому визначенні поняття «фермерське господарство» так і не зазначено, формою підприємницької діяльності яких саме громадян є фермерське господарство. А тому не вбачається можливим відповісти на питання, чи можуть бути членами сімейного фермерського господарства іноземщі або особи без громадянства [12].

Проте, звертаючись до ст. 1 Закону України від 25.08.2019 р. № 2235-ПII «Про громадянство України», громадянин України - особа, яка набула громадянство України в порядку, передбаченому законами України та міжнародними договорами України. А відповідно до цього ж Закону, громадянство України - правовий зв'язок між фізичною особою і Украӥною, що знаходить свій вияв у їх взаємних правах та обов' язках [13].

Отже, 3 аналізу ст. 1 вищезазначеного Закону виходить, що фермерське господарство - це господарська діяльність виключно громадян України. У випадку створення та діяльності фермерського господарства, громадянство - це перш за все формальна вимога, від якої залежить надання землі у власність/оренду, а також надання пільг особі-засновнику. Тобто, при створенні сімейного фермерського господарства повинна бути дотримана вимога щодо громадянства членів такого господарства, навіть незважаючи на наявність сімейного зв' язку між потенщійними членами сімейного фермерського господарства.

3 огляду на вищезазначене, не поділяємо позиції науковців щодо заборони членам однієї сім'ї, навіть за умови дотримання вимоги громадянства засновниками такого (сімейного) фермерського господарства, бути об'єднаними в сімейне фермерське господарство. Законодавство потребує внесення змін щодо кола членів сімейного фермерського господарства шляхом виключення вимоги стосовно громадянства.

Своєю чергою, ст. 3 Сімейного кодексу України визначає, що сім'ю складають особи, які спільно проживають, пов'язані спільним побутом, мають взаємні права та обов'язки [14].

М. М. Осипова й Н. В. Доброва вважають, що для визначення фермерського господарства як сімейного фермерського господарства необхідна наявність двох критеріїв:

1) у його господарській діяльності обов' язково використовується праця членів сім'ї. Залучити до роботи інших громадян можна, але виключно для виконання сезонних та окремих робіт;

2) керівником сімейного господарства обов'язково має бути один із членів сім'ї. Тобто, голова сімейного фермерського господарства не може доручати виконання своїх обов' язків іншій особі [15].

На практищі вимогу закону щодо використання пращі під час ведення господарства суто членами такої сім'ї складно реалізувати, оскільки відсутній механізм моніторингу чи контролю кола осіб, праця яких, фактично, використовується при веденні господарства. Оскільки законодавець, передбачаючи таку норму, не забезпечив механізм контролю чи моніторингу, які б, наприклад, знаходили своє вираження в проведенні перевірок, то можна стверджувати про оціночний характер таких 
норм та неможливість їх реалізації на практищі. У реальному житті це призводитиме до ситуащії, за якої фермерське господарство здійснює свою діяльність як звичайне фермерське господарство, але з податковими пільгами для сімейного фермерського господарства, про які йдеться в наступному абзаці.

Окрім наведеного, змінами до Закону України від 19.06.2003р. № 973-15 «Про фермерське господарство», внесеними відповідно до Закону України «Про внесення змін до ЗУ «Про фермерське господарство» від 31 березня 2016 р., статтю 9 було доповнено новою частиною п'ятою наступного змісту, відповідно до якої фермерським господарствам зі статусом сімейних фермерських господарств надається додаткова державна підтримка в поряпку, передбаченому Законом України «Про державну підтримку сільського господарства України» [16]. Тривалий час реалізувати џю норму на практищі не видавалося за можливе, адже був відсутній реальний механізм законодавчої підтримки дпя сімейних фермерських господарств. Проте, 10 липня 2018 року Закон України «Про внесення змін до Податкового кодексу України та деяких законів України щодо стимулювання утворення та діяльності сімейних фермерських господарств» було внесено зміни до Податкового кодексу України саме з метою стимулювання розвитку фермерського господарства та приведення законодавства до вимог ч. 5 ст. 9 Закону України «Про фермерське господарство» [17].

Відтак, для сімейного фермерського господарства без статусу юридичної особи, законодавець у підпункті б, п. 4 ч. 4 ст. 291 Подактового кодексу України встановлює спрощену систему оподаткування для фізичних осіб-підприємців, які провадять діяльність виключно в межах фермерського господарства, зареєстрованого відпювідно до Закону України від 19.06.2003p. №973-15 «Про фермерське господарство», за умови дотримання сукупності певних вимог, зокрема заборони використання праці найманих осіб.

Законодавець, передбачаючи сукупність вимог, зокрема заборону на використання пращі найманих осіб для отримання спрощеної системи оподаткування, не забезпечив механізм контролю чи моніторингу, які б, наприклад, знаходили своє вираження в проведенні перевірок сімейного фермерського господарства на предмет використання пращі найманих осіб. Недосконалість механізму стимулювання розвитку та діяльності сімейних фермерських господарств у підсумку призводить до зловживання правами, які виникають через неможливість перевірки доброчесності використання таких прав.

Висновки. Зважаючи на давній правотворчий процес у сфері фермерського законодавства, усе ж таки наявні певні прогалини, які необхідно усунути.

Прийняття Закону України від 19.06.2003р. «Про фермерське господарство» підготувало нормативний фундамент для розвитку фермерських господарств. Ним були врегульовані всі основні питання створення, діяльності й припинення діяльності фермерських господарств. Було започатковано нового суб'єкта аграрних правовідносин - фізичну особу-підприємця. Незважаючи на наявність сприяючих розвитку фермерських господарств положень у новому Законі, він містить багато прогалин, що зумовлює необхідність подалышого внесення змін до нього. Зокрема, це стосується визначення поняття фермерського господарства та кола осіб, які можуть бути членами сімейного фермерського господарства, зважаючи на ознаку громадянства, затвердження особливої типової форми установчого документу в разі створення сімейного фермерського господарства одноосібно, контролю за виконанням вимоги «сімейності» щодо способу ведення господарства сімейного фермерського господарства, а також 
контролю за виконанням вимог Податкового кодексу України фізичними особамипідприємцями, які бажають отриматиправо на спрощену система оподаткування та які провадять діяльність виключно в межах фермерського господарства, зареєстрованого відповідно до Закону України «Про фермерське господарство».

\section{Використані джерела:}

1. В Україні зросла кілкість фермерських господарств: сайт від 2020 р. URL:https:// kurkul.com/news/20488-v-ukrayini-zrosla-kilkist-fermerskih-gospodarstv. (дата звернення 15.09.2020).

2. Необхідність впорядкування земельних справ: сайт Facebook від 26.03.2019 p. URL:https://www.facebook.com/zenith.expert/photos/a.1270105649697906/2840555079319614 /?type=3. (дата звернення 18.09.2020).

3. Про селянське (фермерське) господарство: закон України від 20.12.1991 р. (втрата чинності від 29.07.2003 р.) № 2009-XII. URL:https://zakon.rada.gov.ua/laws/show/200912\#Техt. (дата звернення 15.09.2020).

4. Онищенко Н. М. Тенденції та перспективи розвитку законодавства України про фермерські господарства. Вісник Хмельницького інституту регіонального управління та права. 2004, № 1-2, 139-144 c. URL:http://www.univer.km.ua/visnyk/643.pdf. (дата звернення 18.09.2020).

5. Статівка А. М. Аграрне право (оглядові лекції, нормативно-правові акти): навчальний посібник. А. М. Статівка, В. Ю. Уркевич. Харків: Юрайт, 2014. 352 с.

6. Про фермерськегосподарство: Закон України від 19.06.2003 р. (у редакції від 15.08 .2020 p.) № 973-IV. URL:https://zakon.rada.gov.ua/laws/show/973-15\#Text. (дата звернення 18.09.2020).

7. Господарський кодекс України: кодекс України від 16.01 .2003 р. (у редакції від 16.08 .2020 р.) № 436-IV. URL:https://zakon.rada.gov.ua/laws/show/436-15\#Техt. (дата звернення 08.10.2020).

8. Податковий кодекс України: кодекс Украӥни від 02.12.2010 p. (у редакції від 14.10 .2020 p.) № 2755-VI. URL: https://zakon.rada.gov.ua/laws/show/2755-17\#Tеxt. (дата звернення 15.09.2020).

9. Regulation (EU) № 1307/2013 of the European Parliament and of the Council establishing rules for direct payments to farmers under support schemes within the framework of the common agricultural policy and repealing Council Regulation (EC) No. 637/2008 and Council Regulation (EC) No. 73/2009. OJ L 347/608. 20.12.2003 URL:https://eur-lex.europa.eu/legal-content/EN/ TXT/?uri=CELEX\%3A32013R1307\&qid=1604602363079. (дата звернення 15.09.2020).

10. Про затвердження типової форми договору (декларації) про створення сімейного фермерського господарства»: наказ Міністерства аграрної політики та продовольства України від 05.04.2019 p. № 177. URL:https:/ / zakon.rada.gov.ua/laws/ show/z0438-19\#Text.

11. Шемшученко Ю. С. Договір. Юридична енциклопедія: Українська енциклопедія ім. М. П. Бажана. 1998, том № 2, 744 с.

12. Уркевич В. Ю. Правові аспекти створення та функціонування сімейних фермерських господарств. Науковии Вісник Національного університету біоресурсів і природокорисристування Украӥни. 2016, № 243, 67-74 с. URL:http://journals.nubip.edu.ua/ index.php/Pravo/article/view/7508.

13. Про громадянство України: закон України від 18.01.2001 p. (у редакції від 25.08.2019 p.) №2235-III. URL:https:/ / zakon.rada.gov.ua/laws/show/2235-14\#Text. 
14. Сімейний кодекс України: кодекс України від 10.01.2002 p. (у редакції від 03.07.2020 p.) № 2947-III. URL: https://zakon.rada.gov.ua/laws/show/2947-14\#Text. (дата звернення 15.09.2020).

15. Осипова М. М, Доброва Н. В. Фермерські господарства України: особливості, проблеми, перспективи розвитку. Науковий вісник Одеського національного економічного університету. 2016, № 10, С. 98-122.

16 Про державну підтримку сільького господарства України: закон Украӥни від 24.06.2004 p. (у редакції від 16.10.2020 р.) №1877-IV. URL:https://zakon.rada.gov. ua/laws/ show/1877-15\#Техt. (дата звернення 15.09.2020).

17. Про внесення змін до Податкового кодексу України та деяких законів України щодо стимулювання утворення та діяльності сімейних фермерських господарств: закон України від 10.07.2018 р. № 2497-VIII. URL:https://zakon.rada.gov.ua/laws/show/249719\#Text. (дата звернення 15.09.2020).

\section{References:}

1. V Ukraini zrosla kilkist fermerskykh hospodarstv: sait vid 2020 r. (2020) N. p. URL:https://kurkul.com/news/20488-v-ukrayini-zrosla-kilkist-fermerskih-gospodarstv. [in Ukrainian].

2. Neobkhidnist vporiadkuvannia zemelnykh sprav: sait Facebook vid 26.03.2019r. (2019) N. p.URL:https://www.facebook.com/zenith.expert/photos/a.1270105649697906/284055507931961 4/?type=3. [in Ukrainian].

3. Pro selianske (fermerske) hospodarstvo: zakon Ukrainy vid 20.12.1991 r. (vtrata chynnosti vid 29.07.2003 r.) № 2009-XII. (2003) N. p. URL:https://zakon.rada.gov.ua/laws/show/200912\#Text. [in Ukrainian].

4. Onyshchenko, N. M. (2004) Tendentsii ta perspektyvy rozvytku zakonodavstva Ukrainy pro fermerski hospodarstva. Visnyk Khmelnytskoho instytutu rehionalnoho upravlinnia ta prava - Bulletin of the Khmelnytsky Institute of Regional Administration and Law, 1-2, 139-144. URL:http://www.u niver.km.ua/visnyk/643.pdf. [in Ukrainian].

5. Stativka, A. M. (2014) Ahrarne pravo (ohliadovi lektsii, normatyvno-pravovi akty): navchalnyi posibnyk. A. M. Stativka, V. Yu. Urkevych (Eds.). Kharkiv: Yurait. [in Ukrainian].

6. Pro fermerske hospodarstvo: Zakon Ukrainy vid 19.06.2003 r. (u redaktsii vid $15.08 .2020 \mathrm{r}$.) № 973-IV. (2020) N. p. URL:https://zakon.rada.gov.ua/laws/show/973-15\#Text. [in Ukrainian].

7. Hospodarskyi kodeks Ukrainy: kodeks Ukrainy vid 16.01 .2003 r. (u redaktsii vid 16.08.2020r.) № 436-IV. (2020) N. p.URL:https:/ /zakon.rada.gov.ua/laws/show/436-15\#Text. [in Ukrainian].

8. Podatkovyi kodeks Ukrainy: kodeks Ukrainy vid 02.12.2010 r. (u redaktsii vid $14.10 .2020 \mathrm{r}$.) № 2755-VI. (2020) N. p. URL:https://zakon.rada.gov.ua/laws/show/2755-17\#Text. [in Ukrainian].

9. Regulation(EU) № 1307/2013 of the European Parliament and of the Council establishing rules for direct payments to farmers under support schemes within the framework of the common agricultural policy and repealing Council Regulation (EC) No. 637/2008 and Council Regulation (EC) No. 73/2009. OJ L 347/608. 20.12.2003/ (2003) N. p. URL:https://eur-lex.europa.eu/legalcontent/EN/TXT/?uri=CELEX\%3A32013R1307\&qid=1604602363079. [in English].

10. «Pro zatverdzhennia typovoi formy dohovoru (deklaratsii) pro stvorennia simeinoho fermerskoho hospodarstva»: nakaz Ministerstva ahrarnoi polityky ta prodovolstva Ukrainy vid 05.04.2019 r. № 177. (2019) N. p. URL:https:/ /zakon.rada.gov.ua/laws/show/z0438-19\#Text. [in Ukrainian].

11. Shemshuchenko, Yu. S. (1998) Dohovir. Yurydychna entsyklopediia: Ukrainska entsyklopediia im. M. P. Bazhana, vol. 2. [in Ukrainian]. 
12. Urkevych, V. Yu. (2016) Pravovi aspekty stvorennia ta funktsionuvannia simeinykh fermerskykh hospodarstv. Naukooyi visnyk Natsionalnoho universytetu bioresursiv $i$ pryrodokorystuvannia Ukrainy - Scientific Bulletin of the National University of Life and Environmental Sciences of Ukraine, 243, 67-74. in Ukrainian].

13. Prohromadianstvo Ukrainy: zakon Ukrainy vid 18.01.2001 r. (u redaktsii vid 25.08.2019 r.) № 2235-III. (2019) N. p. URL:https://zakon.rada.gov.ua/laws/show/2235-14\#Text. [in Ukrainian].

14. Simeinyi kodeks Ukrainy: kodeks Ukrainy vid 10.01.2002 r. (u redaktsii vid 03.07.2020 r.) № 2947-III. (2020) N. p. URL:https://zakon.rada.gov.ua/laws/show/2947-14\#Text.(data zvernennia 05.11.2020). [in Ukrainian].

15. Osypova, M. M, Dobrova, N. V. (2016) Fermerski hospodarstva Ukrainy: osoblyvosti, problemy, perspektyvy rozvytku. Naukovyivisnyk Odeskoho natsionalnoho ekonomichnoho universytetu - Scientific Bulletin of Odessa National Economic University, 10, 98-122. [in Ukrainian].

16. Pro derzhavnu pidtrymku silskoho hospodarstva Ukrainy: zakon Ukrainy vid 24.06.2004 r. (u redaktsii vid 16.10.2020 r.) №1877-IV. URL:https://zakon.rada.gov.ua/laws/ show/1877-15\#Text. [in Ukrainian].

17. Pro vnesennia zmin do Podatkovoho kodeksu Ukrainy ta deiakykh zakoniv Ukrainy shchodo stymuliuvannia utvorennia ta diialnosti simeinykh fermerskykh hospodarstv: zakon Ukrainy vid 10.07.2018 r. №2497-VIII. (2018) N. p. URL:https://zakon.rada. gov.ua/laws/ show/2497-19\#Text. [in Ukrainian].

Стаття надійшла до редколегї̈ 10.09.2020

Покальчук М. Ю., кандидат юридических наук, ассистент кафедры земельного и аграрного права

Национального юридического университета имени Ярослава Мудрого (г. Харьков, Украина)

Дорошенко Р. В., студент 4 курса Института прокуратуры и уголовной юстищии Национального юридического университета имени Ярослава Мудрого (г. Харьков, Украина)

Шанталій К. С., студентка 4 курса Института прокуратуры и уголовной юстиции Национального юридического университета имени Ярослава Мудрого (г. Харьков, Украина)

\section{ПЕРСПЕКТИВЫ РАЗВИТИЯ СЕМЕЙНЫХ ФЕРМЕРСКИХ ХОЗЯЙСТВ И ПРОБЕЛЫ В ПРАВОВОМ РЕГУЛИРОВАНИИ ИХ ДЕЯТЕЛЬНОСТИ}

Статья посвящена исследованию современного состояния правовой регламентации института фермерства. Проанализированы ряд нормативно-правовых актов времен УССР, регулирующих порядок создания и деятельности крестьянских (фермерских) хозяйств. Авторами освещена эволюция фермерского хозяйства начиная со времен УССР и до современности. 
В статьепроведен анализ понятия фермерского хозяйства сквозь призму отечественного и зарубежного законодательства. Проанализированы Закон Украины от 19.06.2003 р. № 973-15 «Офермерском хозяйстве», Хозяйственный кодекс Украины, Налоговыйкодекс Украиныидр. законодательныеакты, которые устанавливаютправовое регулирование фермерских хозяйств в Украине.

Авторами изучены нормы Закона, регулирующие порядок создания и деятельности семейных фермерских хозяйств. Также исследовано состояние законодательства касаемо пробелов в правовом регулировании фермерских хозяйств.

Ключевые слова: аграрное право; фермерское хозяйство; семейное фермерское хозяйство; аграрные правоотношения; сельское хозяйство; семейное фермерское хозяйство без статуса юридического лица; агропромьшшенный комплекс.

Pokalchuk M.,

Candidate of Law,

Assistant of the Department

of Criminal Procedure Yaroslav Mydryi

National Law University

(Kharkiv, Ukraine)

Doroshenko R.,

4th year student of the Criminal Justice

and Prosecutor's Training Institute of

Yaroslav Mydryi National Law University

(Kharkiv, Ukraine)

Shantalii K.,

4th year student of the Criminal Justice and Prosecutor's Training Institute of

Yaroslav Mydryi National Law University

(Kharkiv, Ukraine)

\section{PROSPECTS FOR THE DEVELOPMENT OF FAMILY FARMS AND GAP IN THE LEGAL REGULATION OF THEIR ACTIVITIES}

The article is devoted to the study of the current state of legal regulation of the institute of farming. A number of normative legal acts of the times of the Ukrainian SSR, which regulated the order of creation and activity of peasant (farmer) farms, are analyzed. The authors cover the evolution of farming from the times of the USSR to the present. A brief historical and legal analysis has been conducted of the legislation on the creation for the first time in Ukraine, 25 years ago, a new type of agricultural subjects of farming. At present, the following types of farms are legally enshrined, which will continue to act according to the law of Ukraine «On farm» from June 19, 2003, and family farms of two types - family farms with the rights of a legal person and family farms without acquiring the status of legal entities, which are a natural personentrepreneur alone or jointly, only members of the same family on the basis of the agreement on the establishment of the family farm. Attention is drawn to the legal conditions of new agreement on the creation of family farming without giving the status of a legal person. Legal problems are clarified concerning taxation State support of family and other farming households, agricultural enterprises according to the requirements of the law of Ukraine «On State support of Agriculture of Ukraine» and the tax code of Ukraine. The article analyzes the concept of farming through the 
prism of domestic and foreign legislation. The Law of Ukraine of June 19, 2003 is analyzed. №97315 "On farming", Commercial Code of Ukraine, Tax Code of Ukraine, etc. legislation that establishes the legal regulation of farms in Ukraine. The authors analyze the provisions of the Law governing the establishment and operation of family farms. These farms to other farms distinguish the following indications: use in their activities of members of the management, which are only members of the same family; their head can only be a member of the respective family, and family farms without legal status - only family member is registered as an individual - entrepreneur and definite agreement on the establishment of the economy. Also, the state of legislation on gaps in the legal regulation of farms was studied.

Keywords: agrarian law; farming; family farming; agrarian legal relations; Agriculture; family farm without the status of a legal entity; agro-industrial complex.

\section{DOI: 10.33766/2524-0323.91.150-159 УДК 343.140.02}

Н. В. Хмелевська, кандидат юридичних наук, адвокат, доцент кафедри кримінального права та процесу Хмельницького університету управління та права імені Леоніда Юзькова (м. Хмельнищький, Україна) e-mail: stamp.ua@gmail.com iDhttps:/ / orcid.org/0000-0002-4492-4868

В. О. Гарматюк, аспірант Хмельницького університету управління та права імені Леоніда Юзькова, головний державний ревізор-інспектор відділу з питань запобігання та виявлення корупції Головного управління ДПС у Хмельницькій області

(м. Хмельнищький, Україна) e-mail: vitaliyagarmatyuk@gmail.com iD https://orcid.org/0000-0003-3867-5049

\section{МІЖНАРОДНІ СТАНДАРТИ ЗАБЕЗПЕЧЕННЯ ЗДІЙСНЕННЯ ПРАВОСУДДЯ В КРИМІНАЛЬНИХ ПРОВАДЖЕННЯХ ЩОДО КОРУПЦЙНИХ ЗЛОЧИНІВ}

У статті проаналізовано підходи до поняття міжнародних стандартів у сфері кримінального судочинства, визначено особливості таких стандартів саме в кримінальних провадженнях щодо корупщійних злочинів та встановлено проблемні аспекти їх застосування, надано обгрунтовані висновки щодо розкриття поняття «міжнародні стандарти забезпечення здійснення правосуддя в кримінальних провадженнях щодо корупщійних злочинів» як встановлених міжнародними договорами, згода на обов'язковість яких надана Верховною Радою України, гарантій здійснення правосуддя щодо фізичних та юридичних осіб у кримінальних провадженнях щодо корупщійних злочинів та які забезпечують як дотримання прав таких осіб у кримінальних провадженнях, так й організацію діяльності судової влади.

Ключові слова: міжнародні стандарти, правосуддя, кримінальне провадження, корупщійний злочин, кримінальне судочинство, гарантії прав.

(C) Хмелевська Н. В.,

Гарматюк В. О., 2020 